\title{
IDEOLOGICAL FACTOR IN MASS COMMUNICATION: HISTORICAL AND THEORETICAL ASPECTS
}

Taras Lylo ${ }^{7}$

\begin{abstract}
The article examines the communication nature of ideology, its capacity to serve as a mediator between ideological principles (theory) and political practice. Apart from that, the author shows that the basic paradigms of communication research are ideologically marked and the dominant paradigm is based on the values of liberal democracy, while representatives of the alternative research paradigm mainly attempt at exposing the inadequacy of liberal pluralist ideology.
\end{abstract}

Keywords: mass communication, ideology, media, Marxism, Liberalism, the mediator

The current understanding of ideology is closely linked to mass communication. Dennis McQuail in his Mass Communication Theory defines ideology as an "organized belief system or set of values that is disseminated or reinforced by communication", noting that "in practice most media content (of all kinds) does so implicitly by selectively emphasizing certain values and norms" [2010, p. 466]. Therefore, communication channels and the media are viewed as a means of reinforcing and disseminating a certain ideology, as well as intermediaries of the ideological influence on people. However, ideology as such has communication potential manifesting itself in a variety of ways in this or that historical period.

The concept of "ideology" was introduced in 1796 by French philosopher Antoine Destutt de Tracy in his work Elements of Ideology [Destutt de Tracy, 1796]. He interpreted ideology as "the science of ideas" that "aims to establish the source of our beliefs, perceptions, and opinions so that we could overcome some of our prejudices and illusions that cause mutual misunderstandings and conflicts between people [Lisovyi, 1997, p. 59]. As we can see, ideology was supposed to offer a consolidation basis at the public and intergovernmental levels in the time of bloody revolutions and wars of the late XVIII and early XIX centuries, making coomunication between antagonistic entities possible. In other words, it was to create a foundation for successful communication, since, according to Volodymyr Rizun, "the communication process can be over-complicated because of disputes and misunderstanding, but communication always has to conclude in perfectaccord $30 \%$ consent means that, unfortunately, only $30 \%$ of communication was implemented... Communication is always a lengthy process at the stage of search for understanding and harmony" [Rizun, 2000]. He believes that communication is the process of search for a result, rather than the result itself. This implies that ideology has a certain communication nature, both actual and potential. For example, under 
the conditions of bipolar confrontation and isolation, the only communication channel between the two antagonist systems was the ideological contact. It determined the confrontation environment, but it was this contact that turned out to be a factor of the collapse of the USSR as a pseudo-communication and pseudo-ideological system that had accumulated a critical degree of lies.

The communication capacity of ideology can be observed not only at the intersystem level, but also within individual systems. According to Jerzy Muszyński [2009, p. 26], a political doctrine as a synthesis of ideology is a kind of a mediator between the ideological principles (theory) and political practice. For instance, the Enlightenment and the associated ideology of Liberalism changed the principle of power legitimation: the sovereign power is vested in the people, rather than the monarch. As V. Lisovyi put it: "Power became dependent on the state of mass consciousness. Political ideologies are a consequence of the democratization of politics, they signify the emergence of the mass human upon the historical stage" [Lisovyi, 1997, p. 60] who has to understand ideas offered by philosophers through their adaptation within ideological doctrines. It is ideology that becomes the mediator between these ideas and mass society.

On the other hand, according to Louis Althusser's theory [1980], communication is a social process this is why it also has to be an ideological process: it is interpretation that makes up the key problem of the ideological part of this process. "Each communication process addresses someone and through this contact positions its participants in certain social relations. When identified as the recipient and responding to own signals, we take part in our own, public, and, therefore, ideological construct" [Fiske, 1999, pp. 217-218].

Analysis of relationships and mutual penetration of ideology and communication gives grounds to state that there exists a certain ontological dependence between them. In other words, the ideological existence in society is preceded by communicational existence. First, as Wilbur Schramm argued, only communication can create community, and therefore society, as a community is a form of social interaction. His predecessor, French scholar Gabriel Tarde in the early twentieth century noted that newspapers contributed to the development of the general public, which, in turn, generated a wide network of variable overlapping groups. Secondly, according to American sociologist Alvin Gouldner [1976], without such a phenomenon of mass communication as the mass media, there would have been no rise of ideology as "a special form of rational discourse", which consolidated in the XVIII and XIX centuries thanks to the press (its conceptual symbolism) as a promoter of the dissemination of ideas and their interpretations. Thirdly, according to C. Wright Mills [1951], there are communications between consciousness and existence that influence people's perception of their existence.

It is complicated to establish the relationships between mass communication and ideology in historical time since despite the fact that the functioning of ideology in the above interpretation of $\mathrm{A}$. Gouldner emerged as a result of the advent of the mass media (the press), the very notion of "ideology" appears much later than its structure and purpose, as de facto ideologies were intellectual inspirers of civilizations' development. When analysing the views of Grzegorz Leopold Seidler, Jerzy Muszyński [2009, p. 35] argues that a manifestation of natural ideology in ancient China was the conception of public relations as a result of the influence of nature and environment. The researcher interprets it as a quasi-ideology, although in this case we deal with mythologemes rather than ideologemes. Subsequently, ideology structurally and deontologically gains a foothold in the classical antiquity, in particular in Plato's idealism and Aristotle's realism that treat the state as a political organization of society. In the era of feudalism, it was necessary to ideologically legalize absolutism and the then social hierarchy, as well as to show its immutability from the time of ancient despotism. Therefore, with certain reservations we can assume that the said legalization had ideological features of conservatism. Next, liberalism ideologically rationalised the collapse of feudalism, 
which, of course, did not imply the expiration of conservatism, on the contrary, in the second half of the $18^{\text {th }}$ and early $19^{\text {th }}$ centuries it gained a footing as a reaction to the French Revolution.

It is noteworthy that at this time the press becomes one of the parts of the political system, an intermediary between the authorities and society, and an essential factor in relations between ideologies and political practice. This was due to the fact that the late $18^{\text {th }}$ and $19^{\text {th }}$ centuries spawned a number of cultural changes (the spread of education, strengthening of super-local communications, increase in cultural needs of new social groups), political changes (participation of new social groups in the political life and, consequently, transformation of social and power structures, emergence of new political parties and public organizations, change of limits of civil liberties, including freedom of speech and the press), social changes (appearance and emancipation of new classes and strata, and, thus, redesigning the system of social forces accompanied with the revolutionary processes of destroying the old social structures).

In the $19^{\text {th }}$ century, the content of newspapers greatly enriched. Daily periodicals published editorials, reports of parliamentary sessions and international news. This increased the potential of influencing the human mind and coincided with the emergence of new political doctrines and ideologies: along with, for instance, Liberalism and Conservatism appear Anarchism, Marxism and Reformism, also having the press at their disposal. These factors triggered the emergence of conditions and needs for theoretical study of both mass communication process and the ideological factor in this process.

This formulation of the problem was greatly influenced by Marxism, including its approaches to the press and its function of political control under conditions of concentrated political power. Despite the fact that Karl Marx could only consider the press, which at the time was just acquiring traits of a mass medium, "the tradition of Marxist analysis of the media in capitalist society is still of some relevance" [McQuail, 2010, p.85] that spawned apologists, reconsideration and criticism prevailing in communication theory for a long time. Marxist theory focuses on the media primarily as a means of disseminating the interests of the ruling class, and on the strong link between ownership and the ideological content of the message. In other words, the media and their influence through representation of reality is economically - and, therefore, ideologically - determined. Karl Marx substantiates this idea in his work The German Ideology [1988], where he argues that the class which owns the means of material production at the same time owns the means of mental production, i.e. it generally owns the thoughts of those who lack the means of intellectual production. Therefore, they dominate as a class and determine the scope and focus of the epoch. They also control the production and dissemination of ideas of their time, and, thus, their views turn into the dominant views of the epoch. Marxists interpret the said representation of reality as false, hence the communication between the ruling class and other social groups is manipulative and seeks to justify or conceal its domination. According to Louis Althusser [1980], it is supported by the ideological state apparatus (ISA), i.e. various specialized public institutions, including the press, radio and television, that make up the so-called "information state apparatus". ISA preserves the domination ofa minority over the majority via open or hidden non-repressive means.

Another representative of the Marxist theory Antonio Gramsci introduces the term "hegemony". First and foremost, it implies ideological domination of the ruling class that rests on economic advantages or violence as well as on consent and loyalty based on the feeling of "common sense" supposedly embedded in the content of hegemony, which is interpreted as constantly reasserted determination of the society state in a discursive way. A prerequisite for this feeling is the general perception of the power of the ruling class and its ideas as a natural and usual, as well as uncritical and largely unconscious way of perceiving and understanding the world. A. Gramsci pointed out that the said hegemony is implemented through literature and art, the education system and 
the media, which "do not determine the reality on their own, but rather provide selective access to definitions for those in power" [McQuail, 2010].

Among Neo-Marxist mass communication studies, special attention should be given to the views of the Frankfurt School representatives (M. Horkheimer, T. W. Adorno, $\mathrm{H}$. Marcuse). In their studies, the consumer is subject to the influence of "the commodification of culture", that is, the mass culture industry as a commodity produced by the media. Such mass culture production is of ideological nature, because the mass media generate patterns that take control over all human activity and function as "false consciousness" in the sense of Karl Marx. The mentioned cultural products "can be exchanged by consumers for psychic satisfactions, amusement and illusory notions of our place in the world, often resulting in the obscuration of the real structure of society and our subordination in it (false consciousness)" [McQuail, 2010]. According to Denis McQuail, this ideological process is usually coupled with our dependence on commercial mass media.

The relationship between ideology and communication is clearly traced in the critical theory of encoding and decoding developed by Stuart Hall [1973], a representative of the Birmingham School. The researcher partly digresses from the issue of uniqueness of the dominant ideology influence rather than the influence itself. He argues that before producing any effects, meeting any needs or being used, a message has to be decoded. This gives rise to the problem of "the desired reading" or the decoded meaning that would be effective, influential, persuasive or instructive and contains a whole range of perceptive, cognitive, emotional, ideological or behavioural consequences" [Hall, 1980, p. 165]. S. Hall dismissed the inevitable correlation between encoding as absolutization of mono-accent ideological structures and decoding, which has the potential to resist the dominant ideology encoded in the message. For the British sociologist, the sphere of decoding is the key locus of ideological struggle ("semantic guerrilla") in the communication process.

According to Nina Zrazhevska, most communication theorists agree that "mass communications support the status quo in society and at the same time shape the audience that needs the kind of values and a culture that corresponds to the majority. This manifests the underlying ideological nature of the media, i.e. legitimization and maintenance of the status quo" [2008]. A similar opinion is held by John Fiske [1999, p. 202], but some theorists, including Nicolas Abercrombie [1980], deny the existence of a dominant ideology in the Western society and associate this with the fact that some citizens do not share the values imposed by state institutions. This problem developed dynamically in the context of research into the media influence on the audience. In the first decades of the $20^{\text {th }}$ century, most scholars influenced by behaviourism believed that certain types of media content cause certain predictable social responses [Lall, 2002 , p. 104]. By the 1940s, the unanimous claims concerning the unilateral and often manipulative influence of the mass media on consumers had subsided. The focus of attention shifted to the view that the media neither shape nor change behaviour, but rather reinforce existing patterns of human behaviour [Lall, 2002, p. 104].

In the studies of the second half of the $20^{\text {th }}$ century, the emphasis was initially placed on the subjective capabilities of information consumers and their ability to limit ideological effects embedded in the message content by means of selection. As a result, the media were viewed as an object of manipulation in accordance with the audience needs (uses and gratifications theory). However, an important issue in this context is what the consumer can choose, because the choice opportunities are directly dependent on the ideological diversity of media supply: where there is no diversity, there is no choice. It can only be simulated. As noted by S. Hall [1982], media actively carry out selection and representation, structuring and formation of dominant values and ideas. However, the media conceal their ideological suggestions and endowed its limiting perspectives with that natural or divine inevitability which makes them appear universal, 
natural and coterminous with 'reality' itself [Hall, 1982, p. 61]. According to Jerzy Olędzki [Olędzki, 2001, p. 44], it is the arbitrary selection, rather than fact falsification that proves to be the main cause of event distortion in messages. The author identifies the following forms (most of which are ideological in nature) of the said distortions in the practice of the most influential news agencies (AP, AFP, Reuters, ITAR-TASS):

1. exaggerated importance of insignificant events;

2. combining isolated facts and presenting them as reflecting the complete image of the situation;

3. imposing the interpretation of events and their consequences upon readers in a way that benefits and serves the interests of certain agencies or multinational corporations;

4. distortion by informing only about the facts that may have a direct impact on the behaviour and consciousness of certain groups of people, activities of enterprises or governments;

5. concealment of events that do not meet the interests of the country of origin of the mass medium.

Jerzy Olędzki's views are based on the approach of a proponent of the "agenda setting" theory in the media Bernard Cohen [Cohen, 1963, p. 13], who argued that the media might have little success in dictating us what we should think, but they are extremely successful in dictating us what we should think about. In other words, they point out what is to be considered worth our attention and important, regardless of the real situation.

The subsequent theoretical studies again started viewing the media as capable of exercising ideological influence on the audience. However, this effect was characterized as completely dependent on the structure of media ownership and their market orientation rather than self-contained. Hence, the media are seen as intermediaries in the ideological influence of the capitalist class and lose whatever autonomy practices and ideas of their employees [Kulyk, 2010, p. 107]. Radical criticism of such dependence is represented in the study by Edward Herman and Noam Chomsky, who in their work "Manufacturing consent: the Political Economy of the Mass Media" [Herman, Chomsky, 1988] interpret the American media as an institution subordinated to the propaganda model. "A propaganda model focuses on this inequality of wealth and power and its multilevel effects on mass-media interests and choices. It traces the routes by which money and power are able to filter out the news fit to print, marginalize dissent, and allow the government and dominant private interests to get their messages across to the public" [Herman, Chomsky, 1998, p. 2]. The authors of the said study believe that the main components of such a propaganda model or set of news "filters" include: 1) the scope, concentration of ownership, the owner's wealth, and profit orientation of most mass media; 2) advertising as the main source of income for the media and an effective tool for latent ideological messaging; 3 ) dependence of the media on the information provided by the government, business and pro-government "experts"; 4) "flak" as a means of disciplining the media; and 5) "anticommunism" as a national religion and control mechanism, which lost its importance after the collapse of the Soviet Union, "but this is easily offset by the greater ideological force of the belief in the "miracle of the market «(Reagan)" [Herman, Chomsky, 1998, p. XVII]. Journalism, according to Edward Herman and Noam Chomsky, learned this neoliberal ideology and helped to make non-market views seem utopian. These two theorists believe that the mass media support the system due to the "market forces", internalized assumptions and self-censorship. At least two facts in the recent history of American television expressly illustrate the above effect. In 1998, executives of American Broadcasting Company (ABC) shelved report of its leading investigative correspondent Brian Ross. His program covered numerous cases of paedophilia in amusement parks, i.e. Disneyland parks. The parks, as 
well as the $\mathrm{ABC}$ network, are owned by concern Walt Disney Company. Another example is related to program "Today" of large TV station NBC concerning faulty valves on US nuclear power plants. The journalists failed to mention that these hazardous valves were used at the power stations of General Electric as well. It is this concern that was the owner of NBC at the time.

Although some researchers [Muszyński, 2009] suggest that the rise of information civilization may put an end to ideology, the interpenetration of media and ideology is evident not only in historical time. Today, there are levels that make the interpenetration a natural thing. First, it is the functional level. The mass media and ideology play an orientation role. "The media are turning into the main instrument of ideological orientation for people in the globalizing world. In other words, the ideological orientation function of the media activity is transforming into a universal information process developing in the global information space parallel to the ideological process". In addition, E. Dmitriev [2007, p. 36-39] argues that the key mechanism for implementing the ideological orientation activity of the media is the public opinion formation, which is identical to the ideological process, and on which, according to Bourdieu [2002], journalism depends more than politics. Secondly, this is the ontological level, because the media provide the environment where ideology and symbolic structures exist and function, where "ideology manifests itself as a system of meanings that ensure comprehension and interpretation of value judgments about the world and society" [Tuzykow, 2002, p. 123-133].

Furthermore, contemporary researchers of the ideological content in media discourse (first of all, V. Kulyk [2010]) when writing about the main components of the ideological influence of the media include on that list creation of a national identity along with maintenance of the current public perceptions and, thus, the current social order (the status quo) and underpinning normalizm as a worldview. This is due to the fact that "on the one hand, the media reflect the idea of the reality of these communities (national ones- T.L.) and belonging of each person to one of them that is common for most members of the audience/public; and, on the other hand, they maintain and partly impose a positive perception of such belonging" [Kulyk, 2010, p. 134]. The above said implies that the media and ideology (especially national one) have an integrative function, i.e. the potential to unite society based on deliberately formed objectives and generally accepted values. As it was mentioned the beginning, the ideological doctrine is aimed at neutralizing social and socio-cultural differences. This is embedded primarily in its all-national nature.

Thus, we can conclude that the basic paradigms of communication studies are ideologically marked. Specifically, the dominant paradigm is based on the values of liberal democracy, while representatives of the alternative research paradigm mainly attempt at exposing the inadequacy of liberal pluralist ideology.

\section{References:}

ABERCROMBIE, N., HILL S., TURNER B.S. (1980), The Dominant Ideology Thesis, London, George Allen \& Unwin.

ALTHUSSER, L. (1980), Ideology and ideological state apparatuses, [in:] Lenin and Philosophy and other Essays, New York and London, Monthly Review Press.

BOURDIEU, P. (2002), 0 telewidinjie i zurnalistykie, Moskwa, Institut eksperementalnoj socyologyy.

COHEN, B. C. (1963), The Press and Foreign Policy, Princeton, Princeton University Press.

DESTUTT DE TRACY,A.L.C. (1796), Eléments d'idéologie, Gallica bibliothèque numérique, http://gallica.bnf.fr/ ark:/12148/bpt6k41799v.

DMITRIEV, E. (2007), Osnownyje faktory izmenenyja roli SMI w processie globalyzacyi informacyonnogo prostranstwa [in:] Fylosofia i socyalnyie nauki, Issue No. 3. 
FISKE, J. (1999), Wprowadzenie do badań nad komunikowaniem, Wrocław, Wydawnictwo Astrum. GOULDNER, A. (1976), The Dialectic of Ideology and Technology, London, Macmillan.

HALL, S. (1980), Encoding, decoding in the television discourse, [in:] S Hall,D. Hobson, \&P. Lowe, (eds). Culture, Media, Language, London, Hutchinson.

HALL, S. (1982), "The rediscovery of "ideology ": return of the repressed in media studies", [in:] Gurevitch M., Bennett T., Curran J., Woollacott J., Culture, Society and the Media, London and New York, Routledge.

HALL, S., Encoding/Decoding, [in:] Durham, M. G.,Kellner, D. M., (ed). Media and Cultural Studies(2006), Padstow, Blackwell Publishing.

HERMAN, E.S., CHOMSKY, N., Manufacturing Consent: The Political Economic of Mass Media, Pantheon Books, New York, 2002.

KULYK, B. (2010), Dyskurs ukrainskyh medij: identychnosti, ideologii, wladni stosunky, Kyjiw, Krytyka.

LALL, DZH. (2002), Mass-media, komunikacija, kultura: globalnyj pidhid, Kyjiw, K. I. S.

LISOWYI, W. (1997). Kultura- ideologija-polityka, Kyjiw, Wyd. im. O. Teligy.

MARX, K., ENGELS, F. (1988), Niemieckaja ideologyia, Moskwa, Polytyzdat.

MCQUAIL, D. (2010), Mass Communication Theory, Los Angeles, London, New Delhi, Singapore, Washington D.C., SAGE Publication.

MILLS, C.W. (1951), White Collar, New York, Oxford University Press.

MUSZYŃSKI, J. (2009), Cywilizacja informatyczna - świat bez ideologii, Toruń, Wydawnictwo Adam Marszalek.

OLĘDZKI, J. (1999), Komunikowanie na świecie, Warszawa, Wydawnictwo Aspra.

RIZUN, W. (2000), Zagalna harakterystyka masowo informacijnoji dijalnosti, Elektronna biblioteka instytutu zhurnalistyki, http://journlib.univ.kiev.ua/index.php?act=article\&article=35.

TUZYKOW, A. (2002), Mass-media: ideologya wydymaya i newydymaya, [in:] Polys, Issue No. 5.

ZRAZHEWSKA, N. (2008), Ideologichni ta cinnisni konteksty media w teoriah komunikacji, Elektronna biblioteka Instytutu Zhurnalistyki, http://journlib.univ.kiev.ua/index.php?act=article\&article=2407. 